\title{
The Analysis of Teachers' Code Switchings Based on The Perceptions of The Eighth Grade Students of SMP Negeri 2 Sawan
}

\author{
Juliadnyana I. G. ${ }^{1 *}$, Suarnajaya I. W. ${ }^{2}$, Ramendra D. P. ${ }^{3}$.
}

${ }^{123}$ Department of English Education, Universitas Pendidikan Ganesha

\section{A R T I C L E I N F O \\ Article history: \\ Received 25 February \\ 2020 \\ Received in revised \\ Form 29 March 2020 \\ Accepted 20 April 2020 \\ Available online 29 May \\ 2020}

Keywords:

Code switching, type of

code switching, function

of code switching,

perception.

\begin{abstract}
A B S T R A C T
This research aimed to identify the types of code switching and the students' perception about code switching used by the English teachers in the eighth grade students of SMP Negeri 2 Sawan. This research was conducted in descriptive qualitative design. The subjects of this research were the eighth grade students and the eighth grade English teachers. The instruments used in this study were observation sheet, questionnaire, and interview guide. The results of this research showed that there were three types of code switching used by the English teachers. The data showed there were (31.7\%) of intra sentential code switching, (54.8\%) of inter sentential code switching and (13.4\%) of inter personal code switching.The results of the questionnaire showed that the average responses of the students were $(70.74 \%)$, it means that students were catagorized to have positive perception about the use of code switching by the English teachers. The interview shows that the students had positive response about the use of code switching by the English teachers. There were two reasons concerning the students' positive answer, that is, code switchings that make the students understand the material more easily, and code swicthings that reduce the students' stress in learning.
\end{abstract}

\section{Introduction}

It is often said that language is a basic need of human beings in a society. According to Lepi (2013), language is a part of everyday communication, and it becomes a key in interaction. It means that language is used in everyday communication, including formal and informal situations in order to send message or gather information from other people. In general, language is used to communicate and build relationship with each other. When people interact with each other in society, they have to use a language. Language is very important, because without language, people will find it difficult to interact with other people.

Language has a great role in human life, because all of the interactions are always associated with language itself. People interact to other people through language. Usually they choose a language based on the context in which the language is used. In society, many people prefer using more than one languages in a communication to using one language only. People who use two or more languages in communication tend to understand and feel comfort in a conversation. When people use two languages in their conversation, it is known as bilingual.

Bilingual is an individual who has minimal competency in the use of one or two more languages. According to Birner (2003), bilingual person is someone who speaks two languages. The person may become bilingual either by acquiring two languages at the same time in their childhood or by learning a second language. Jendra (2010) has the same thought in defining bilingual. He mentions that bilingual is a person who has an aptitude in using more than one language equally.

In daily communication, most people do not realize that they switch their language from one language to another. According to Hoffman (1991), there are seven reasons why people switch their languages or code when they communicate with each other. One of them is repetition, which is used for clarification. It means that if they are not able to express an idea in one language, they switch their language into another language to make the listener understand what they mean. In terms of sociolinguistics, this is known as code switching. 
According to Myers-Scotton (1993), code switching is the selection by bilingual or multilingual form from minor language in utterances of major language during the same conversation. It means that code switching is the use two or more languages in the same conversation. In this case, people use more than two languages to convey meaning of their conversation for some particular reasons.

Since it is known as a way to produce a smooth communication. Nowadays code switching is usually used in teaching process. In terms of education, many teachers usually use code switching in teaching process. Code switching is usually used when the teachers switch their languages from one language to another. It helps the students easily catch the point of learning materials. Code switching is often used by the teachers when they teach specific subject especially English.

In Indonesia, English becomes very popular language since it needs to be learnt. According to Kanwal and Kurshid (2012), English is called as an international language. It means that English has an important role in communication. English is known as a foreign language and it is not easy to master English very well especially in teaching and learning process. Therefore, code switching is usually used in teaching and learning process to make the material easy to be understood by the students.

According to Cook (2001:413), teachers' code switching should be planned ahead because it can contribute to a more efficient understanding of a specific topic or to be a part of the L2 learning. It is important not to prevent students from using their first language but to encourage them to use the second language in as many situations as possible and to find out when and why code switching should occur.

Code switching is one of the communication strategies for bilingual education in the classroom (Mati, 2008). It increases students' motivation in learning English. In other word, code switching can help the teachers to communicate with the students in teaching and learning process. Therefore, English teachers have to ensure that the students have a better understanding about learning material even they have to use two languages in teaching process.

Meanwhile, to make the students mastering English itself, the teachers have to teach English in target language. Therefore, the use of code switching should be minimal in teaching English. According to Robert (2013: 3), the use of code in teaching English for the students should be minimal to ensure that teaching and learning in target language is optimal. But In reality, the use of code switching is always used by the teachers in teaching English in any situation.

In teaching process, the students' understanding is also affected by the teacher's code switching, because the students as the receiver in teaching process and all of the students are given different stimulus in terms of language used. Therefore, to ensure that the effectiveness of the use of code switching in teaching process is good or bad, it can be seen from the students themselves especially through their perception.

According to Shama (2008), perception is a cognitive process, in which an individual collects, organizes, and interprets data from the environment to obtain the meaning about an object or a situation. According to Ryan et. al (1995), in teaching and learning process, students' perception is highly correlated with their overall rating of teaching effectiveness. In this case, through the students' perception the teachers will know good or bad used of code switching in teaching process is.

In the relation with the use of code switching, students' perception can be used to ensure the effectiveness of code switching in teaching process, because the students act as the receiver when the English teacher teaches them using code switching. Unconsciously, when the teacher uses code switching in teaching and learning process the students recieve the information from the teacher using two different languages. It means that the students can assume weather the use code switching has an important role in teaching process or not.

In this case, the intensity of code switching used by the teachers is high in junior high school. It can be assumed that junior high school as the transition phase when the students try to learn English more deeply. Based on the preliminary observation conducted in SMP Negeri 2 Sawan, many English teachers were categorized as bilingual teachers since they taught the students using two different languages. They usually switched their languages from English to Bahasa Indonesia in the same utterance. The teachers used two languages in order to help students understand the material, because not all of the materials could be taught using English. When the teachers changed language from one to another, it allowed the teacher to explain difficult material to students easily. Based on the English teachers' point of view, the use of two languages in teaching process is good and important in helping students to get a better understanding about the material that is being taught.

Considering the phenomenon above, this study was intended to analyze the students' perception of the eighth grade students about the use of code switching and the types of code switching used by the eighth grade English teachers in SMP Negeri 2 Sawan. This research covered students' perception about the function of code switching used in teaching and learning process. 
There are six theories that are to be used in this research, namely code, code switching, types of code switching, Code switching as a technique of teaching English as a foreign language, general function of code switching, and perception. The first theory is code. Code is like a system to help someone to communicate with each other, when he or she start to communicate with each other they have to choose particular codes to express their feelings. According to Stockwell (2002, as cited in Adipratama, 2014: 2), code is a symbol of nationalism that is used by people to speak or communicate in a particular language, dialect, register, accent, or style on different occasions and for different purposes. According to Similarly and Wardaugh (2010, as cited in Adipratama, 2014: 2), code can be defined as a system used for communication between two or more parties in any occasions.

The second theory is code switching. According to Gal and Wardaugh (1998, as cited in Ari, 2012), code switching is a conversational strategy used to establish, cross, or destroy group boundaries to create, evoke, or change interpersonal relations with their right obligation. It means that code switching has purpose and function in communication.

Hoffman (1991), states that code switching is alternate of two languages or linguistics varieties with the same utterance or during the same conversation. It means that code switching is another way to change our language to another language that is epoken durning the conversation. According to Hoffman (1991), there are seven reasons why people switch their language such as: talking about a particular topic, interjection, quoting somebody else, being emphatic about something, repitition for clarification, intention of clarifying the speech content for the interlucutor, and expressing group identity.

According to Myers-Scotton (1993), code switching is the selection by bilingual or multilingual form from minor language in utterances of major language during the same conversation. It means that code switching occurs when the speakers are able to speak more than one language. He also says that there are three types of code switching namely: inter sentential, intra sentential, and inter personal switching.

The third theory is type of code switching. According to Myers- scotton (1993), there are three general types of code switching, namely inter sentential code switching, intra sentential code switching, and inter personal code switching. Inter sentential code switchng is the one of code switching types where the base of the language can be changed based on the speaker's need to create another meaning. Intra sentential switching is a simple type of code switching. It switches phrase including a single word. The occurrence will not change the language base. Inter personal code switching occurs in terms of language base and occurrence which makes it similar to inter-sentential code switching.

The fourth theory is code switching as a technique of teaching English as a foreign language. According to Canale and Swain (1979), the model of communicative competence which focuses on the acquisition is not only limited to grammatical competence but also including sociolinguistic competence, discourse competence, and strategy competence as well, and literature teaching is an excellent resource for acquisition of these competence. Using code switching in teaching literature becomes a powerful technique of teaching English which is used by the teachers to make it easier to the students to learn English.

According to Robert (2013: 3), code is a useful strategy to make meaning clear and transfer information easily. However for English language learning, the use of code in teaching should be minimal to ensure that teaching and learning in target language is optimal.

The fifth theory is general function of code switching. According to Olmedo-Williams (1981), there are several functions of code switching in a bilingual classroom, namely regulatory (Reg), emphasis (Emp), attention (AtT), lexicalization, clarification (Cla), sociolinguistic play (SoP), addressee specification (AdP), and instruction (Int).

The sixth theory is perception. Perception is the process of individual thinking about an object or thing. Different individuals have different perception because they think differently. According to Furberg (2011), perception is an individual intepretation about a situation or stimuli based on individual prior experience. According to Goldestin (2010), perception is everything you see, hear, taste, feel, or smell created by the mechanisms of your senses. This means that what you are perceiving is determined not only by what is "out there", but also by all the senses.

In relation of teaching effectiveness of the teacher and the students in the classroom, the perception of the students allows the teacher to find the appropirate teaching technique to teach the students for some subjects. According to Mahfoodh \& Pandian (2011), through students' perception the teacher is able to know the negative and positive of the teacher's feedback. According to Shama (2008), perception is described as cognitive process where an individual collects, organizes, and interprets information from the environment. 


\section{Methods}

The article is a descriptive qualitative research where the focus was to describe the students' perception about code switching used by the English teachers in teaching and learning porcess. According to Dantes (2012:51), descriptive qualitative research is a research that seeks to describe a phenomenon or event sitematically based on what happening.

The setting of this research was conducted in SMP Negeri 2 Sawan. It is one of junior high schools in Singaraja, which is located in Bungkulan.The subjects of this research were the eighth grade students and the English teachers of SMP Negeri 2 Sawan. The object of this research was the types of code switching that were used by the eighth grade English teachers in teaching process. This research also covered analysis of the students' perception toward code switching used by the English teachers in teaching process.

This research used non participant observation. According to Given (2008: 561), non-participant observation is a qualitative research strategy to collect primary data in social world without doing an interaction directly with the participant.

There were several instruments used in this research namely, observation sheet, interview guide and questionnaire.

In this research the data analysis that proposed by Miles and Huberman (2009) was used to analyzed the data. The data analysis including: data collection, data reduction, data display and conclusion drawing.

\section{Result And Discussion}

There were 246 utterances that catagorized as code switching used by the English teachers in teaching process during the observation. Based on Myers - scotton (1993) classification, there are thee types of code switching used by the English teachers, there are (1) intra sentential code switching, (2) inter sentential code switching, and (3) inter personal code switching.

There are different numbers of code switching that was used by each English teacher. the highest number of code switching used by the third teacher that were 71 utterances catagorized as code switching. Then followed by the first teacher that were 67 utterances of code switching. Then, the forth teacher that were 58 utterances of code switching. meanwhile the lowest number of code switching used by the second teacher that were 50 utterances of code switching. from 246 utterances that produced by the English teachers, 135 utterances catagorized as inter sentential code switching. Then, 78 utterances catagorized as intra sentential and the last were 33 utterances catagorized as inter personal code switching.

The example of intra sentential code switching could be seen in the utterance "For the example, hello this is Ratana atau good morning ratna is speaking" In her utterance, it showed that she used intra sentential code switching to give the students the example of greeting expression used on the telephone. In this case, this utterance can be catagorized as intra sentential code switching because the teacher switched her language from English to Bahasa Indonesia in the same utterance. The occurrence of switching language did not change the basic language. The language that was switched by th teacher occured in the word "atau". The word "atau" in Bahasa Indonesia is used as a conjuctive to mark a choice between several things. When the teacher switched her language from English to Bahasa Indonesia, it did not have any effect to the meaning of the utterance. The word "atau" was used to allow the students to differenciate both example that given by the teacher.

Inter sentential code switching used by the English teachers could be seen in the utterance "That is for greeting someone on the telephone! Itu contoh bagaimana memberikan salam dalam telepon ya" The teacher used two different languages to clarifying about the example given. It is catagorized as inter sentential code switching because the teacher produced two different languages which occured in different sentence. When the teacher used inter sentential code switching the basic language of teacher's utterance also changed from English to Bahasa Indonesia.

The example of Inter personal code switching used by the English teachers could be seen in the conversation :

"Teacher : Apa itu benar? Ada yang punya jawaban lain?

Student : Benar buk.

Teacher : Yes the asnwer is correct. How about number two? Who can answer?"

In this case the conversation above catagorized as inter personal code switching because the teacher switched her language when she did a conversation with a student. When the teacher switched 
her language, she used Bahasa Indonesia first and after replied by the students the teacher switched her language into English. The teacher switched her language to clarify that the student's answer was correct.

Based on the questionnaire that was given to the students about their perception of code switching used by the English teachers. The average percentage of the students' perception catagorized as positive. Based on the criterion that has been made, the range $70 \%-84 \%$ is catagorized as good response. In this case, the students showed their good response toward the use of code switching. To specified the data to be clear, the students' response of the questionnaire were also viewed based on Goldstin's (2010) theory. According to Goldstin (2010), perception can be observed from individual view, feeling, and response about an object or thing. Based on the result of the questionnaire, $10.98 \%$ of the students agree with code switching used by the teachers. Then, $7.49 \%$ strongly agree, $5.79 \%$ doubtful, $6.81 \%$ disagree, and $2.26 \%$ strongly disagree. It could be concluded that most of the students preferred to choose 'agree' for the statements in the questionnaire.

Based on the interview process, there were two reasons of the students' positive perception toward the use of code switching by the English teachers. The first reason was because code switching make the students understand the learning material more easily. From 23 students interviewed, 74\% of the students answered the use of code switching in teaching process allowed them to understand the learning material more easily more than when the teachers used target language in teaching process. As stated by Olmedo \& Williams (1981), the function of code switching is to clarify the ambiguity or to give a brief explanation for the students. This catagory can be in the form of repeating, pharaphrasing and elaborating ideas in another language.

The second reasons was code switching reduced the students' stress in learning process. From 23 students interviewed, $26 \%$ of the students answered that code switching was appropirate for them, because it reduced their stress in learning. The use of code switching in teaching process made the students feel secure and become communicatively because they were in confortable learning situation. It is related with Olmedo - Williams (1981), that is code switching used to keep somebody happy in teaching process. It can be said that the use of code switching in teaching process decreased the students' stress in learning English. Therefore the students felt relaxed in teaching process because the students were able to catch the learning material being explained by the English teachers.

\section{Conclussion}

There were three types of code switching used by the eighth grade English teachers in teaching process. There were intra sentential, inter sentential and inter personal code switching. Based on the accumulation, there were 246 utterances produced by the English teachers, catagorized as code switching. In this case, seventy eight utterances were classified as intra sentensial code witching, one hundred and thirty five utterances as inter sentential code switching and thirty three utterances as inter personal code switching.

Besides that, students also had positive perception about the use of code switching in teaching process. It can be seen from the form the students' response in the questionnaire and the interview. There were various reasons of the students to give positive response about the use of code switching in teaching process. Here are the reasons of the students' positive perception about code swithing used in teaching process. The first reason was code switching made them easy to understand the material being taught by the teachers. It means that the function of code switching in the classroom was to clarifiy the material to allow the students to understand the material more easily. The second reason was the use of code switching reduced the students' stress in learning process. Students implied that code switching is a good tool to transfer information more easily and to improve their understanding.

Based on the conclusion above, the researcher would like to purpose some suggestions as follows: (1) Code switching has been found to be perceived positively by the students. This positive perception is related to their high views, responses, and feeling. Therefore, the use of code switching by the English teachers are good for students to make them have a better understanding about the learning material. (2) It is suggested for the other teachers in different subject to use code switching in teaching process, due that code switching can be used not only to teach English subject but also to teach the other subjects in different level. (3) It is highly recommended for other researcher to conduct other studies about students' perception toward code switching in other scope research and different level. 


\section{Reference}

Birner, B. 2003. "Bilingualism: The Linguistic Society Of America". Avaliable at http://www.linguisticsociety.org/sites/default/files/Bilingual.pdf. (Accessed on 2th November 2016).

Canale, M, \& Swain, M. 1980. Theritical bases of communicative approach to second language teaching and testing. Applied linguistics, 1, 1-47.

Cook, V. 2001. "Code Switching In The English Classroom: what teachers do and what their students wish they did". Avaliable at http://www.diva-portol.org. (Accessed on 2th November 2016).

Furberg, E. 2011. "How do students' perceptions of their education change over time? - exploring perceptions of learning, responsibility, engagement and satisfaction". Theis (publish thesis), Umea University, Sweden. Avaliable at http://www.diva-portal.org/smash/get/diva2:419082 /FULLTEXT01.pdf. (Accessed on 7th june 2016).

Given, L. M. 2008. Encyclopedia of Qualitative Research Method. London: SAGE Publish.

Goldestin, E.B. 2010. "Sensation and Perception". Eighth Edition. WADSWORTH CENGAGE Learning. Avaliable at https://www.google.co.id/search?ie=UTF-8\&q=perception+book+pdf\&sa=X\&ved=0 ahUKEwiI9 rImq7PAhVFOJQKHTo9DhQQ1QIIBg. (Accessed on 26th june 2016).

Hoffman, C. 1991. An Introduction to Bilingualism. Second Edition. New York: Longman Press.

Jendra, M. I. I. 2010. Sociolinguistics: The Study of Societies' Languages. Yogyakarta: Graha Ilmu.

Kanwal. W \& Khurshid. F. 2012. Strength for Today and Bright for Tomorrow. Avaliable at http://languageinindia.com. (Accessed on 26th june 2016).

Lepi, K. 2013. 50 "Things You Probably Didn't Know About Languages". Avaliable at http://www.edudemic.com/language-quiz/. (Accessed on 26th june 2016.)

Mahfoodh, O. H. A., \& Pandian, A. 2011. “A Qualitative Case Study of EFL Students' Affective Reactions and Perceptions of Their Teacher' Written Feedback". English Language Teaching, 4(3), 4-9.

Mati, Xola. 2008. Using Code Switching as a Strategy for Bilingual Education in the Classroom. AEAA Conference.

Myers \& Scotton, C. 1993. "Contact Linguistics: Bilingual Encounters and Grammatical Outcomes”. Oxford University Press. (unpublished thesis). English Education Department, Ganesha University of Education: Singaraja.

Olmedo \& Williams, L. 1981. "Functions of Code Switching In A Spanish/English Bilingual Classroom". Paper presented at the first Delawere Symposium on Language studies.

Pradnyani, I. A. K. P. 2014. “The Teachers' and Students' Perception About Demotivating Factors on The Students' Speaking Skill of 2nd Grade of Senior High School In SMA Negeri 1 Seririt". Thesis (unpublished thesis) English Education Department, Ganesha University of Education: Singaraja.

Patton, M.Q \& Cochran, M. 2002. "A Guide to Using Qualitative Research Methodology". Avaliable at http://fieldresearch.msf.org/msf/bitstream/10144/84230/1/Qualitative+research+methodology. pdf. (Accessed on 1st November 2016).

Robert Modupoela, Olagunju. 2013. "Code Switching As Teaching Strategy: Implication For English Language Teaching and Learning In A Multilingual Society". Osun state Polytechnic, Iree, Nigeria. IOSR journal of Humanities and Society Science (IOSR-JHSS). Vol. 14, Issue 3,93 -97. Avaliable at http://www.iosrjournals.org/iosr-jhss/papers/Vol14-issue3/P01439294.pdf?id=6710. . Accessed on 7th March 2016). 
Ryan, J.,\& Harrison, P. 1995. “The Relationship Between Individual Instructional Characteristic and The Overall Assessment of Teaching Effectiveness Across Different Instructional Contexts". Research in Higher Education, 36(5), 577-594.

Sanjaya, H. W. 2013. Penelitian Pendidikan: Jenis, Metode dan Prosedur. Edisi Pertama. Kencana Publish.

Sari, G. A. K. 2013. “The Students' Perception on The Implementation of Team Teaching Model and Their English Learning Motivation at Tenth Grade of SMKN 3 Singaraja In Accademic Year 2012/2013". Thesis (unpublished thesis) English Education Department, Ganesha University of Education: Singaraja.

Savenye,W.C. and Rhonda S. R. 2001. "Quantitative Research Issues and Method: An Introduction For Educational Technologiest". Avaliable at http://www.aect.org/ed/edtech/edl/pdf/40.pdf. (Accessed on 14th July 2016).

Sert, 0. 2005. "The Function of Code Switching In ELT Classroom". Avaliable at http//:iteslj.org/Articles/Sert-CodeSwitching.html. (Accessed on 12th March 2016).

Shama. N. 2008. "Concept of Perception and Factors Affect Perception". Avaliable at http://ideallibrary.com.on/pdf. (Accessed on 10th December 2015).

Sovlin. 1960. "Survey Research Method”. Belmont, CA: Wadsworth.

Stockwell, A. R. A. 2014. "Factor Influencing The Use of Code Switching In Walk The Talk 2 Program". Avaliable at http://webcache.googleusercontent.com/search?q=cache:fZFUuywZyPMJ:journal. unnes.ac.id/sju/index.php/rainbow/article/download/4045/3671+\&cd=5\&hl=en\&ct=clnk\&gl=id. (Accessed on 9th December 2015).

Subedi, B. P. 2016. "Using Likert Type Data in Social Science Research: Confusion, Issues and Challengers". International Journal of Contemporary Applied Sciences. Avaliable at http://ijcas.net. (Accessed on 26th june 2016).

Travers. 1978. PENELITIAN PENDIDIKAN: Jenis, Metode dan Prosedur. Edisi Pertama. Kencana Publish.

Wardaugh, A. R. A. 2014. "Factor Influencing The Use of Code Switching In Walk The Talk 2 Program". Avaliable at http://webcache.googleusercontent.com/search?q=cache:fZFUuywZyPMJ:journal. unnes.ac.id/sju/index.php/rainbow/article/download/4045/3671+\&cd=5\&hl=en\&ct=clnk\&gl=id. (Accessed on 9th December 2015).

Wardaugh, R. 1998. An Introduction to Sociolinguistics. Third Edition. Massachusetts: Blackwell Publisher Inc. 